\title{
Effects of Bureaucratic Behavior,
}

\section{Organizational Culture and Leadership on Public Services in the Local Government of}

\section{Gorontalo}

\author{
Robin Pakudu
}

Pascasarjana, Universitas Negeri Gorontalo, Gorontalo, Indonesia

\begin{abstract}
Public services operated by the government agencies in Gorontalo were not in accordance with procedures. People almost were not informed about public services they could obtained. They were also reluctant to complain about the poor services. In fact, public services by government agencies had been regulated in Law of 2007 on The Second Amendment to Regulations Number 3 of 2005 on Duties and Authorities of Regents and Deputy Regents as well as Regional Government Officials in Performing Technical Tasks. The objective of this research was to find effects of bureaucratic behavior, organizational culture, and leadership on public services in the local government of Gorontalo. This research used survey method. Data were collected using several instruments i.e. observation, interview, documentation, questionnaire, and literature review. Validity test was conducted using the value of Standardize Loading Factor (SLF); while reliability test was using the value of Cronbach Alpha (CA). The research findings showed that bureaucratic behavior, organizational culture and leadership simultaneously provided positive effects for public services in the government agencies of Gorontalo.
\end{abstract}

Keywords-bureaucratic behavior, organizational culture, leadership, public services.

\section{INTRODUCTION}

Today, public services complying with procedures are still unable to meet the public's expectation. Public hardly has any idea of how they access public services in accordance with the standard procedure set out by the government. They are also reluctant to complain about bad services they got, just accepting the modest services willingly. Employees in the service department should provide equal services for all people. Public services are run by an individual or group of people or particular agency to provide assistances and facilities for public. Therefore, it must be operated indiscriminately and equally for all people to achieve particular goals. As a result, professional services can be provided.

Service problems have been normatively set out under the Law Number 25 of 2009 on Public Services and Reagent Regulation Number 4 of 2007 on Second Amendment over Reagent Regulation Number 3 of 2005 on Tasks and Authorities of Reagents and Deputy Reagents as well as Regional Government Officials in Performing Technical Tasks. Nevertheless, problems of the government bureaucracy in providing services for public are still unsolved. The problems are is related to not only issues of power relation, but also various negative sigma attaching to the government bureaucracy that still remains as the most concerned problem. Based on the result of assessment of local government compliance with the Law Number 25 of 2009 on Public Services, in 2018, the government of Gorontalo was only able to stay in the yellow zone despite the zone insufficiency. Therefore, the ombudsman of the Republic of Indonesia repeatedly provided policy options for local leaders that were still in the yellow or red zone by giving reprimand and encouraged all leaders in public service units regarding the implementation of standardized public services to.

The issues had made me interested in proving to what extent the bureaucratic behavior, organizational culture, and leadership improved public services. The objective of this research is to find whether or not bureaucratic behavior, organizational culture, and leadership simultaneously affect public services in the government of Gorontalo. 


\section{RESEARCH METHOD}

The research used survey research method. Information was collected from respondents using questionnaires. Generally, the notion of survey was limited to the notion of sample survey where information was collected from a half of population to represent all population (Singarimbun and effendi, 1982:14). In term of the type of research, it was explanatory research using a quantitative approach. Quantitative approach was performed in the inferential study (to test hypothesis). However, in term of the level of explanation, it was associative research. According to Sugiyono (2002), associative research was research aimed to find the correlation between two or more variables.

The research population was civil servants in ten offices and agencies carrying out public services in the local government of Gorontalo. Samples collected in this research were 98 civil servants selected using proportional random sampling. Meanwhile,the public was only used as supporting samples (second opinion).

\section{Data Collection Technique}

In this research, survey was performed by collecting data from samples. Instruments used in this research were observation, interview, documentation, questionnaires, and literature review. There were two types of data used in this research i.e. primary and secondary data. The primary data were respondents' response to questionnaires we distributed. Meanwhile, the secondary data were documents in the local government of Gorontalo obtained from the literature review.

Data analysis was performed by converting response categories into score and determining the categories Likert scale. According to Sugiyono, (2011:147), the Likert scale was used to measure attitude, opinion, and perception of an individual or a group of people towards social phenomena. The response of each questionnaire was ranged from very positive to very negative.

Table 1. Likert Scale Category

\begin{tabular}{|c|c|l|}
\hline No. & Scale & \multicolumn{1}{|c|}{ Criteria } \\
\hline & 5 & Excellent (SB) \\
\hline & 4 & Good (B) \\
\hline & 3 & Average (CB) \\
\hline & 2 & Adverse (K) \\
\hline & 1 & Bad (TB) \\
\hline
\end{tabular}

\section{Validity Test}

Validity test was performed to find whether or not questions in the questionnaire used as the data collection instrument were valid and able to measure the construct in this research. Validity of the variables with reflective indicators was tested by referring to Standardize Loading Factor (SLF). Igbaria et al. in Wijayanto (2008) suggested that a good SLF score was $\geq 0.30$. Hair (2010) suggested SLF score $\geq 0.5$ showing that convergent validity had been achieved or SLF $\geq 0.7$.

\section{Reliability Test}

Reliability test was used to test whether or not respondents' responses on the question were consistent or stable from time to time. The measurement of reliability in this research was performed using one shot method by referring to cronbach alpha score. The questionnaire was considered reliable when respondents' responses to the question were consistent or stable from time to time. In this research, reliability test was performed in the construct indicators that had passed validity test and validated. According to Latan and Temalagi, (2013) a construct or variable was considered reliable when the Cronbach Alpha score was $>0.70$.

\section{Statistical Data Analysis Technique}

Data analysis used to prove the proposed hypothesis was Partial least square-path model (PLS-PM) analysis. According to Yamin(Kurniawan et al., 2011), PLS-PM was data analysis technique used to analyze the correlation between a set of variable blocks.

\section{FINDINGS}

\section{Validity and Reliability Tests for Reflective Indicators}

For the reflective construct, several measurement types were used i.e. (1) convergent validity that could be seen from Standardized Loading Factor (SLF); (2) square root of average variance extracted (AVE); (3) Composite Reliability (CR); and (4) Cronbach Alpha (CA). Based on validity and reliability tests of a construct, we found that SLF score of all items in the indicator of public service variable was $(\mathrm{Y})>0.5$. Therefore, correlation between each measurement item (indicators) and the construct was valid. CR score of public service variable was 0.965 . If CR $>0.8$, the construct had a high reliability or was reliable. Moreover, if CR was > 0.6, it was quite reliable ((Yamin and Golesorkhi, 2010). CA score of public service variable was 0.96 . If CA was $\geq 0.5$, it was good; whereas if it was $\geq$ 0.3 , it was sufficient. 


\section{Statistical Data Analysis}

1. Structural Model (Inner Model) and Direct Relation (Direct Effect) Testing among Variables
Structural model in PLS was evaluated using path coefficient; while the significance was tested based on the value of t-statistic and p-values of each path.

Table 2. Direct Relation of Path Coefficient, $t$-Statistic, and $p$-values

\begin{tabular}{|l|c|c|c|c|c|}
\hline & $\begin{array}{c}\text { Original } \\
\text { sample (O) }\end{array}$ & $\begin{array}{c}\text { Sample } \\
\text { mean (M) }\end{array}$ & $\begin{array}{c}\text { Standard deviation } \\
(\mathbf{S T D E V})\end{array}$ & $\begin{array}{c}\text { t-statistics } \\
(\mathbf{O} / \mathbf{S T D E V})\end{array}$ & p-values \\
\hline BO $\rightarrow$ PEL PUB & 0.201 & 0.197 & 0.087 & 2.306 & 0.022 \\
\hline KEP $\rightarrow$ PEL PUB & 0.518 & 0.526 & 0.083 & 6.224 & 0 \\
\hline PB $\rightarrow$ PEL PUB & 0.201 & 0.202 & 0.084 & 2.376 & 0.080 \\
\hline
\end{tabular}

Source: Processed data, 2018

\section{2. $\quad$ F Test (Simultaneously Testing)}

$\mathrm{F}$ test was a test conducted to regression coefficient simultaneously. This test was conducted to find simultaneous effects of all independent variables in the model on dependent variables. $F$ test in this research was used to test significant effects of bureaucracy, organizational culture, and leadership on public services simultaneously.

Table 2 shows that path coefficient of organizational culture (BO) on public services (PEL PUB), leadership (KEP) on public services (PEL PUB) and bureaucratic behavior (PB) on public services (PEL PUB) were $0.087,0.083$ and 0.084 respectively. All coefficients were positive, which meant that the direct relation among variables was directly proportional. Bureaucratic behavior (PB), organizational culture (BO), and leadership (KP) on public services (PEL PU) was 61.512. All coefficients were positive, so they simultaneously provided significant effects for public services.

$T$-statistic value among variables was higher than the value of t-table (1.97). The p-value was below 0.05 , so all variables provided significant effects for public services in the local government of Gorontalo.

\section{Statistical Analysis on Variable Descriptive}

In this part, the result of distributed questionnaire processed using SPSS 17 version was explained descriptively. The statistical description was as follows:

Table 3. Description of Bureaucratic Behavior Variable (X1)

\begin{tabular}{|c|c|c|c|c|c|c|c|c|}
\hline \multirow{2}{*}{ No. } & \multirow{2}{*}{ Indicator } & \multirow{2}{*}{ Item } & \multicolumn{5}{|c|}{ Frequency $(\%)$} & \multirow{2}{*}{ Mean } \\
\hline & & & 1 & 2 & 3 & 4 & 5 & \\
\hline \multirow{2}{*}{1.} & \multirow{2}{*}{ Work Division (X1.1) } & 1 & 0.0 & 0.0 & 3.1 & 52 & 44.9 & 4.42 \\
\hline & & 2 & 0.0 & 0.0 & 3.1 & 52.0 & 44.9 & 4.37 \\
\hline \multicolumn{8}{|c|}{ Mean X1.1 } & 4.35 \\
\hline \multirow{2}{*}{2.} & \multirow{2}{*}{ Responsibility (X1.2) } & 1 & 0.0 & 0.0 & 7.1 & 49.0 & 43.9 & 4.37 \\
\hline & & 2 & 0.0 & 0.0 & 7.1 & 49.0 & 43.9 & 4.13 \\
\hline \multicolumn{8}{|c|}{ Mean X1.2 } & 4.25 \\
\hline \multirow{2}{*}{3.} & \multirow{2}{*}{ Discipline(X1.3) } & 1 & 0.0 & 0.0 & 7.1 & 49.0 & 43.9 & 4.38 \\
\hline & & 2 & 0.0 & 0.0 & 7.1 & 49.0 & 43.9 & 4.31 \\
\hline \multicolumn{8}{|c|}{ Mean X1.3 } & 4.34 \\
\hline \multirow{2}{*}{4.} & \multirow{2}{*}{ Unity of Command (X1.4) } & 1 & 0.0 & 0.0 & 14.3 & 32.7 & 53.1 & 4.39 \\
\hline & & 2 & 0.0 & 0.0 & 15 & 44.4 & 39.2 & 4.21 \\
\hline \multicolumn{8}{|c|}{ Mean X1.4 } & 4.30 \\
\hline
\end{tabular}




\begin{tabular}{|c|c|c|c|c|c|c|c|c|}
\hline \multirow{3}{*}{5.} & Unity of Direction (X1.5) & 1 & 0.0 & 0.0 & 11.2 & 46.9 & 41.8 & 4.31 \\
\cline { 3 - 9 } & 2 & 0.0 & 0.0 & 13.3 & 56.1 & 29.6 & 4.17 \\
\hline
\end{tabular}

Source: Processed data, 2018

Table 3 shows the data of the result of analysis on the indicator of bureaucratic behavior variable (X1). In respect of the work division indicator (X1.1), employee placement according to their training or expertise was more preferable. Employees would have an ability to provide services optimally. For responsibility indicator (X1.2), public expected that while providing services, employees should willingly listen to their complaints. In term of discipline (X1.3), they expected that employees arrived punctually because they usually had arrived at the office prior to the service hour. For the unity of command indicator (X1.4), the most expected service was that employees should perform their works according to the instruction, or the standard operational services. For the unity of direction indicator (X1.5), employees were expected to work according to the authority given. Their tasks were not supposedly overlapping, because each employee had to work based on his/her authority.

Table 4. Description of Organizational Culture Variable (X2)

\begin{tabular}{|c|c|c|c|c|c|c|c|c|}
\hline \multirow{2}{*}{ No. } & \multirow{2}{*}{ Indicator } & \multirow{2}{*}{ Item } & \multicolumn{5}{|c|}{ Frequency $(\%)$} & \multirow{2}{*}{ Mean } \\
\hline & & & 1 & 2 & 3 & 4 & 5 & \\
\hline \multirow{2}{*}{1.} & \multirow{2}{*}{ Involvement (X2.1) } & 1 & 0.0 & 0.0 & 12.2 & 31.6 & 56.1 & 4.44 \\
\hline & & 2 & 0.0 & 0.0 & 12.2 & 31.6 & 56.1 & 4.15 \\
\hline \multicolumn{8}{|c|}{ Mean X2.1 } & 4.30 \\
\hline \multirow{2}{*}{2.} & \multirow{2}{*}{ Consistency (X2.2) } & 1 & 0.0 & 0.0 & 14.3 & 44.9 & 40.8 & 4.27 \\
\hline & & 2 & 0.0 & 0.0 & 14.3 & 44.9 & 40.8 & 4.34 \\
\hline \multicolumn{8}{|c|}{ Rerata X2.2 } & 4.31 \\
\hline \multirow{2}{*}{3.} & \multirow{2}{*}{ Adaptation (X2.3) } & 1 & 0.0 & 0.0 & 16.3 & 41.8 & 39.8 & 4.12 \\
\hline & & 2 & 0.0 & 0.0 & 16.3 & 41.8 & 39.8 & 4.23 \\
\hline \multicolumn{8}{|c|}{ Rerata X2.3 } & 4.18 \\
\hline \multirow{2}{*}{4.} & \multirow{2}{*}{ Mission (X2.4) } & 1 & 0.0 & 0.0 & 13.3 & 56.1 & 29.6 & 4.14 \\
\hline & & 2 & 0.0 & 0.0 & 13.3 & 56.1 & 29.6 & 4.31 \\
\hline \multicolumn{8}{|c|}{ Mean X2.4 } & 4.23 \\
\hline
\end{tabular}

Source: Processed data, 2018

Table 4 shows the data of the result of analysis on the indicator of organizational culture variable (X2). In term of involvement indicator (X2.1), employee improvement provided a huge contribution. The improvement had to be performed properly and continuously, so employees would feel satisfied and comfortable with their careers. In the consistency indicator (X2.2), the second item provided a greater contribution, in which the score adopted referred to the essence contained in the organization. In term of adaptation (X2.3), people expected that employees understood their intention and character. In the mission indicator (X2.4), most people expected that employees were able to build an effective team to provide services. 
Table 5. Description of Leadership Variable (X3)

\begin{tabular}{|c|c|c|c|c|c|c|c|c|}
\hline \multirow{2}{*}{ No. } & \multirow{2}{*}{ Indicator } & \multirow{2}{*}{ Item } & \multicolumn{5}{|c|}{ Frequency $(\%)$} & \multirow{2}{*}{ Mean } \\
\hline & & & 1 & 2 & 3 & 4 & 5 & \\
\hline \multirow{2}{*}{1.} & \multirow{2}{*}{ Interpersonal role(X3.1) } & 1 & 0.0 & 0.0 & 23.5 & 45.9 & 26.3 & 3.95 \\
\hline & & 2 & 0.0 & 0.0 & 23.5 & 45.9 & 26.3 & 4.03 \\
\hline \multicolumn{8}{|c|}{ Mean X3.1 } & 3.99 \\
\hline \multirow{2}{*}{2.} & \multirow{2}{*}{ Information role(X3.2) } & 1 & 0.0 & 0.0 & 20.4 & 53.1 & 25.5 & 4.12 \\
\hline & & 2 & 0.0 & 0.0 & 20.4 & 53.1 & 25.5 & 4.00 \\
\hline \multicolumn{8}{|c|}{ Mean X3.2 } & 4.06 \\
\hline \multirow{2}{*}{3.} & \multirow{2}{*}{ Decision role (X3.3) } & 1 & 0.0 & 0.0 & 17.3 & 39.8 & 41.8 & 4.22 \\
\hline & & 2 & 0.0 & 0.0 & 17.3 & 39.8 & 41.8 & 4.26 \\
\hline \multicolumn{8}{|c|}{ Mean X3.3 } & 4.24 \\
\hline
\end{tabular}

Source: Processed data, 2018

Table 5 shows the data of the result of analysis on the indicator of leadership variable (X3). For interpersonal role indicator (X3.1), face to face interaction between a leader and subordinate while stating an action, existence, and experience provided a greater contribution. In information indicator (X3.2), the first item provided greater contribution. In providing information, leader should use straightforward words. In decision role indicator (X3.3), the most expected improvement was that while making decision, leader should always carefully consider the potential effects that might appear.

Table 6. Description of Public Services Variable $(Y)$

\begin{tabular}{|c|c|c|c|c|c|c|c|c|}
\hline \multirow{2}{*}{ No. } & \multirow{2}{*}{ Indicator } & \multirow{2}{*}{ Item } & \multicolumn{5}{|c|}{ Frequency (\%) } & \multirow{2}{*}{ Mean } \\
\hline & & & 1 & 2 & 3 & 4 & 5 & \\
\hline \multirow{2}{*}{1.} & \multirow{2}{*}{ Transparency (Y1) } & 1 & 0.0 & 0.0 & 24.5 & 54.1 & 18.4 & 3.88 \\
\hline & & 2 & 0.0 & 0.0 & 24.5 & 54.1 & 18.4 & 3.99 \\
\hline \multicolumn{8}{|c|}{ Mean Y1 } & 3.94 \\
\hline \multirow{2}{*}{2.} & \multirow{2}{*}{ Accountability(Y2) } & 1 & 0.0 & 0.0 & 24.1 & 49.0 & 23.5 & 3.83 \\
\hline & & 2 & 0.0 & 0.0 & 24.5 & 49.0 & 23.5 & 3.91 \\
\hline \multicolumn{8}{|c|}{ Mean Y2 } & 3.87 \\
\hline \multirow{2}{*}{3.} & \multirow{2}{*}{ Conditional(Y3) } & 1 & 0.0 & 0.0 & 31.6 & 52.0 & 10.2 & 3.67 \\
\hline & & 2 & 0.0 & 0.0 & 31.6 & 52.0 & 10.2 & 3.67 \\
\hline \multicolumn{8}{|c|}{ Mean Y3 } & 3.67 \\
\hline \multirow{2}{*}{4.} & \multirow{2}{*}{ Participatory(Y4) } & 1 & 0.0 & 0.0 & 13.6 & 41.8 & 22.4 & 3.82 \\
\hline & & 2 & 0.0 & 0.0 & 31.8 & 41.8 & 22.4 & 3.81 \\
\hline \multicolumn{8}{|c|}{ Mean Y4 } & 3.82 \\
\hline \multirow{2}{*}{5.} & \multirow{2}{*}{ Right to equality (Y5) } & 1 & 0.0 & 0.0 & 24.5 & 49.0 & 23.5 & 3.99 \\
\hline & & 2 & 0.0 & 0.0 & 24.5 & 49.0 & 23.5 & 3.89 \\
\hline \multicolumn{8}{|c|}{ Mean Y5 } & 3.94 \\
\hline 6. & Balanced between right and responsibilities (Y6) & 1 & 0.0 & 0.0 & 30.6 & 41.8 & 22.4 & 3.95 \\
\hline
\end{tabular}




\begin{tabular}{|l|l|l|l|l|l|l|l|c|}
\hline & 2 & 0.0 & 0.0 & 30.6 & 41.8 & 22.4 & 3.81 \\
\hline Mean Y6 & & & \\
\hline
\end{tabular}

Source: Processed data, 2018

Table 6 shows the data of the result of analysis on the indicator of public service variable (Y). From transparency indicator (Y1), the first item provided the greatest contribution, in which service systems in each department had already used technology. In accountability indicator (Y2), the second item provided the greatest contribution, in which the existing service systems were expected to comply with the minimal service standards. In term of conditional (Y3), both items provided equal contributions, in which employees were expected to have ability in providing fast services for the community. It was also expected a compatibility between the result of provided services and regulation set out. In participatory indicator
(Y4), most people expected that in term of service provision, there had be compatibility between the service requirement and the service type. In the right to equality indicator (Y5), employees were expected to provide services without discrimination. In the balance indicator (Y6), employees were expected to meet their obligation in providing services to the community properly and according to the procedure.

\section{Hypothesis Testing}

Hypothesis testing based on the result of processed data using t-test is indicated in Table 7.

Table 7. The Result of Hypothesis Testing

\begin{tabular}{|c|c|c|c|c|c|}
\hline \multicolumn{2}{|c|}{ Variable } & \multicolumn{2}{c|}{ Path Coefficient } & \multirow{2}{*}{ p-value } & Description \\
\cline { 1 - 4 } X & Y & $\begin{array}{c}\text { Original } \\
\text { Sample }\end{array}$ & $\begin{array}{c}\text { Standard } \\
\text { Deviation }\end{array}$ & & \\
\hline PB (X1) & PEL PUB & 0.201 & 2.376 & 0.018 & Positive significant \\
\hline BO (X2) & PEL PUB & 0.201 & 2.306 & 0.022 & Positive significant \\
\hline KEP (X3) & PEL PUB & 0.518 & 6.224 & 0 & Positive significant \\
\hline
\end{tabular}

The test result showing bureaucratic behavior, organizational culture, and leadership simultaneously affecting public services in the local government of Gorontalo was presented in able 8.

Table 8. The Result of Simultaneous Regression Coefficient Test (F Test)

ANOVA ${ }^{b}$

\begin{tabular}{|l|l|l|l|l|l|}
\hline Model & Sum of Squares & Df & Mean Square & F & Sig. \\
\hline 1 Regression & 4017.642 & 3 & 1339.214 & 61.512 & $.000^{\mathrm{a}}$ \\
Residual & 2046.532 & 94 & 21.772 & & \\
Total & 6064.173 & 97 & & & \\
\hline
\end{tabular}

a. Predictors: (Constant), X3, X2, X1

b. Dependent Variable: X4

Based on Table 8, the value of $F_{\text {count }}$ was 61.512 with the value of sig 0.00. The value of $F_{\text {count }}$ was higher than $F_{\text {table }}$ and the value of sig was lower than 0.05 . Therefore, $\mathrm{H}_{0}$ was rejected and $\mathrm{H}_{\mathrm{a}}$ was accepted. It meant that bureaucratic behavior, organizational culture, and 
leadership simultaneously provided significant effects for public services in the local government of Gorontalo.

\section{DISCUSSION}

\section{The Effect of Bureaucratic Behavior on Public Services}

The result of hypothesis testing showed that bureaucratic behavior provided positive and significant effects for public services in the local government of Gorontalo (coefficient value of 2.376 and p-value of 0.018). It meant that the better bureaucratic behavior, the better services provided by the government agencies for public.

Data in Table 3 show the result of description of variable with five types of indicators i.e. working division, responsibility, discipline, unity of command, and unity of direction.

\section{Working Division}

Based on the result of interview, it was necessary for the local government of Gorontalo to pay attention to the placement of the head of department and employees. Scientific background was needed in addition to the academic achievement for employee placement because neglected scientific background could be an obstacle when employees did not know their works. Employees could not focus on their work. When people went to the service center for administration and needed explanation related to the administration procedure, they could not give any proper explanation. This case supported theory proposed by Fayol (2013) that working division had to be specialized or divided into smaller elements, so the working outcome and effectiveness of employees would improve along with the improvement of their ability and expertise on the work they carried out.

\section{Responsibility}

Table 3 shows that in term of responsibility, while providing services, employees were not good enough because they could not make response to public's complaints properly. When public needed information, a sense of responsibility to establish communication related to the service procedure could not be delivered properly by the employees. Therefore, people who needed service was not satisfied with the service. They thought that the employees were reluctant to establish communication with them, so their complaint could not be responded well.

\section{Discipline}

The analysis result showed that employees were expected to be able to come to the office punctually. Local government of Gorontalo was expected to emphasize discipline enforcement to employees because it was related to their responsibilities as civil servants who were required to be ready to provide services to the public. The public often complained about employees' discipline. Services that had to be provided in the morning and at the predetermined time were often given late. Even there were also other service counters that had yet provided services. Likewise at noon, when services should have been started, people still needed time to wait the employees in the service counter.

\section{Unity of Command}

The questionnaire result showed that the statement of "doing the work according to instructions" had a high frequency score. Therefore, it was necessary for the local government of Gorontalo to remind their staff continuously. They were required to do their works based on the standard services regulated in Law No. 25 of 2009 , not based on their own desire. The understanding of public services should be continuously maintained and evaluated. The local government should check whether their staffshad already performed the work according to their work field or only based on their desires. As a result, there would be no complain from the people. However, in fact, the standard had not been met.

\section{Unity of Direction}

The questionnaire result showed that the statement of "doing the work according to the authority" had a higher frequency score. It meant that each employee had to perform the work based on the agreement, not based on their desire. Therefore, it required evaluation and control from the leader. The leader should issue official instructions for employees to ensure the working procedures was in accordance with the service standard. Instructions from the leader to subordinate had to be in accordance with the procedure because when there was no instruction, there would be two instructions in one work and the service could not be provided optimally to the people. It was in line with the 14 principles of management according to Fayol (2013) on authorities and responsibilities between leader and subordinate; authorities should be equal with responsibilities.

\section{The Effect of Organizational Culture on Public Services}

The result of hypothesis testing showed that organizational culture provided positive and significant effects for public services in the local government of Gorontalo with a coefficient value of 2.306 and $p$-value of 0.022 . 
Data in Table 4 shows the result of description of variable with four types of indicators i.e. involvement, consistency, adaptation, and mission.

\section{Involvement}

The questionnaire result showed that the statement "prepared and sustainable employee improvement" had a higher frequency score. Therefore, it was important for the local government of Gorontalo to pay attention to the improvement of their employees. They should make a plan for prepared and sustainable employee improvement. Employees had right to improve. They should be given opportunity to make improvement. To make a fair and equitable employee improvement, employee improvement program was made carefully based on scientific methods rooted in skill and education needed by agencies relevant to the job needed. The improvement was for both non-career and career objectives for junior or senior employees and conducted through training and further studies. The employee improvement was an activity required to be performed by the local government of Gorontalo. It would broaden and enhance employees' knowledge, ability, and skill suitable with the demand of their job. It was in line with a theory proposed by Pratt, L. and Denison, D (2000:168). It argued that involvement was the key factor in organizational culture. Active involvement from organizational members affected organizational performance, particularly management, strategy, organizational strategy, organizational structure, transaction costs, and so on.

\section{Consistency}

Table 4 shows that the statement "organizational identity externally had a connection with organizational image" provided a higher frequency score. Therefore, it was important for local government to pay attention to employees who did not comply with values and rules. In term of service, work overlapping often happened. Job desks of some employees were unclear. For example, one day, a letter delivered by a customer was received by an employee. On the next day, when the employee wanted to check the letter, he/she forgot where he/she put the letter. It happened because the employee worked in two divisions, administration and service divisions at the same time. People assumed that this would slow down the service process they obtained.

\section{Adaptation}

The result of analysis result on adaptation indicator showed that the statement "understanding people character" had a higher frequency score. It indicated that people were asking the service procedure operated by the local government of Gorontalo moved into technological era. To respond to this challenge, every OPD leader had to be aware of this era development known as distribution. Government should try to transform the public service system into machine. The enforcement would force public sector to cut off the bureaucratic chains for the government performance. When public sector was able to manifest this threat, the government would be able to improve their public services. When quality of public service increased, people's trust in government would be restored.

\section{Mission}

The questionnaire result showed that the statement "prioritizing public interest" provided a higher frequency score. It was important for the local government of Gorontalo to place public as government partner, so the government was able to make an interpretation on a source based on information presented by the source. While providing services, every agency should presented their service standard so that the public as the recipient of the service understood it properly. The standard had to be well socialized by each employee working in providing services for people. Therefore, information delivered by the employee met the service standard known by people.

\section{The Effect of Leadership on Public Services}

The result of hypothesis testing showed that leadership provided positive and significant effects for public services in the local government of Gorontalo with standard deviation of .244 and p-value of 0 .

Table 5 shows the result of description of variable with three types of indicators i.e. interpersonal role, information role, and decision role.

\section{Interpersonal Role}

The questionnaire result showed that the statement "in delivering much kind information, the leader must do it face to face to establish a good open communication" provided a higher frequency score. It meant that communication between a leader and subordinate was not good enough. It was necessary for each leader in each agency of local government of Gorontalo to understand that communication was one of the important factors for people in daily life both individually and in group or organization. It was also important for each agency to be able to cover the gap between a leader and subordinate (employee), employee and people as the public to establish a better relationship, especially in public services. It was in line with the theory of interpersonal relation needs proposed by $\mathrm{Li}$, Lee and Lai (2009) that each human had three interpersonal needs which were control, inclusive and affection. The fundamental of this theory was that human needed other 
people as social beings. This theory explained that the relation among individuals should present something in a particular condition to create something satisfying the needs of interpersonal relation.

\section{Information Role}

The result of analysis on information role showed that the statement "leader delivered information with straightforward words" had a higher frequency score. It showed that leaders in the government environment of Gorontalo had to understand that one of the characteristics of a good leader was being able to communicate with the subordinate well. Effective communication ability for a leader was absolute. A leader should be able to give a right direction to subordinates, to engender work enthusiasm for subordinates and to make right evaluation of subordinate performance.

\section{Decision Role}

The questionnaire result showed that the statement "appreciating and respecting subordinates' opinion and being kind, not discriminating" had a higher frequency score. It was important for leaders in the government agency of Gorontalo to understand that one of the functions to achieve the goal required to be performed by leaders was how the leader could make decision by carefully considering both potential positive and negative impacts. In the reality of decision making, the head of department and agency in the local government of Gorontalo tended to use their own leadership styles, either in autocratic or paternalistic style. It caused internal conflicts affecting employees' performance and impacted service provisi for public. It was in line with a theory proposed by Rasoolimanesh et al. (2016). In making decision, one had to choose the best among available various alternatives.

\section{The Effect of Bureaucratic Behavior, Organizational Culture and Leadership on Public Services}

The result of hypothesis testing showed that public services were strongly affected by bureaucratic behavior, organizational culture and leadership variables.

Table 6 shows the result of description of variable with six types of indicators; such as transparency, accountability conditional, participative, right to equality and balanced rights and responsibilities.

\section{Transparency}

The questionnaire result showed that the statement "service system via internet" had a higher frequency score. Local government of Gorontalo had to understand that in this digital era, internet users using smartphone in Gorontalo continuously increased from year to year. Besides, access connecting Gorontalo (the regency) and Gorontalo (the city) was close enough. Consequently, the local government of Gorontalo was challenged to transform public services of each agency, from conventional services into technology-based public service products. As a result, activities related to service system could be carried out via internet.

Benefits obtained by the local government of Gorontalo using technology-based services were:

a. Efficiency in cost and time

b. Increase in output service productivity and number of service users

c. As the means to socialize government performance and program

d. Increase in public satisfaction index, so public trust in government can be restored

Benefits obtained by people using technology-based services were:

a. Efficiency in cost and time, no need to come to service counters

b. No need to queue, all procedures and documents can be processed online

c. Fast and right access because it was already online based services

d. Information given was all official and informative

\section{Accountability}

The questionnaire result showed that people more expected service system complying with minimal service standard. This should be considered by each government agency providing services. They should reconsider their governance inseparable from the basic principles of good governance (transparency, participation, and accountability as the main element). Terminology of good governance was yet standard, but there were a lot of definitions that tried to convey the meaning of good governance. However, it could not be denied that good governance was considered an important element to promote national welfare. Therefore, it was important for employees in each agency to understand that while providing service, they should meet the governance of service operational standard. The understanding mattered, because the government was not serving themselves but the society. As a consequence, regarding service provision, the service standards under the Law Number 25 of 2009 had to be considered. The government should bring benefit for society. They had to also avoid to be a difficult and exclusive bureaucracy. The demand of good governance 
and society critics for the low quality of public service forced government to come up with innovation. The innovation was absolutely required to quickly overcome problems faced by society.

\section{Conditional}

The result of data analysis showed that the statement "the speed of service from employees" and "employees' ability in providing services" had an equal frequency scores. Those statements had to be considered by each employee in the local government of Gorontalo. Essentially, service was a series of activities, so the service process should be performed regularly and continuously, covering all organizational life of society. The intended process was carried out by fulfilling needs between service receivers and providers. For this reason, each employee had to understand that service was the main activity for people engaging in service field, both commercial and noncommercial, where the activity was more intended to provide service for society (public or general services) that did not look for profit, but devotion-oriented.

\section{Participatory}

The analysis result showed that the statement "services must be provided indiscriminately" had a higher frequency value. This showed that employees in service department should provide service for all of people regardless their ethnicity or religion. The equal service should be given because public services were carried out by an individual, a group or an agency to provide assistance and facility for society. Therefore, the service provision had to be done indiscriminately to achieve certain goals. This public service was getting important because it always related to general public with various interests and goals. Employees assigned in public services had to be aware that they worked in a government agency, a bureaucratic organization operating public services.

\section{Right to Equality}

The questionnaire result showed that the statement "a right to provide services" had a higher frequency score. This should be noted by each employee of the local government agencies of Gorontalo. In service provision, the following public service standards should be met:
a. Service procedures
b. Fulfillment time
c. Service products
d. Service costs
e. Facilities and infrastructures
f. Employees' competence in service provision

This was in line with a theory proposed by Sinambela (2010) that public services were a fulfillment of wants and needs of society by state officials.

\section{CONCLUSIONS}

According to data analysis, bureaucratic behavior, organizational culture and leadership simultaneously provided positive and significant effects for public services in the local government of Gorontalo. Improvement carried out in each aspect would improve the quality of public services in each government agency, which certainly would satisfy people obtaining the services. In the future, the local government of Gorontalo is expected to pay attention to the employee placement and assignment. The placement and assignment should be done according to their scientific background. It is important to establish procedures for assigning and placing leaders and employees to comply with applicable rules. Employees' consistency in providing services also has to refer to applicable values and rules in the government of Gorontalo.

\section{REFERENCES}

[1] Banks, F. E. (2000) 'Kyoto negotiations on climate change: an economic perspective', Energy Sources.

[2] Berry, L. L., Parasuraman, A. and Zeithaml, V. A. (1988) 'The service-quality puzzle', Business Horizons.

[3] Brata, A. A. (2003) 'Dasar-Dasar Pelayanan Prima', (Jakarta: PT. Elex Media Komputindo, 2003).

[4] Chomitz, K. et al. (1999) What Do Doctors Want? Developing Incentives for Doctors to Serve in Indonesia's Rural and Remote Areas.

[5] Corcoran, S. (2009) 'Defining Earned, Owned And Paid Media', Forrester Research Blog.

[6] Davis, K. (1967) 'Understanding the social responsibility puzzle', Business Horizons.

[7] Denhardt, R. B. and Denhardt, J. V. (2000) 'The new public service: Serving rather than steering', Public Administration Review.

[8] Erikson, E. (1968) Youth: Identity and crisis, New York, NY: WW.

[9] Fayol, H. (2013) 'Principios de Henry Fayol', los 14 principios de henry fayol.

[10] Fesler, J. W. (1948) 'The Administrative State; A Study of the Political Theory of American Public Administration. By Dwight Waldo. (New York: Ronald Press Company. 1948. Pp. viii, 227. \$5.00.)', American Political Science Review.

[11] Gist, J. R. (1989) 'Decision Making in Public Administration', in Handbook of Public Administration.

[12] Hair, J. F. et al. (2012) 'An assessment of the use of partial least squares structural equation modeling in marketing research', Journal of the Academy of Marketing Science. 
[13] Hakim, A. (2017) 'KONTRIBUSI LINGKUNGAN KERJA, PERILAKU KEPEMIMPINAN DAN MOTIVASI KERJA TERHADAP KINERJA PEGAWAI BALAI WILAYAH SUNGAI SULAWESI', Jurnal Manajemen.

[14] Hanif, N. (2005) Teori dan Praktik Pemerintahan dan Otonomi Daerah, PT Grasindo.

[15] Hennala, L., Parjanen, S. and Uotila, T. (2011) 'Challenges of multi-actor involvement in the public sector front-end innovation processes: Constructing an open innovation model for developing well-being services', European Journal of Innovation Management.

[16] Hersey, P. and Blanchard, K. H. (1969) 'Management of Organizational BehaviorPrentice-Hall Inc., 1969 (Cloth and Soft cover. Soft cover \$3.95)', Academy of Management Journal.

[17] Juneman, Meinarno, E. A. and Rahardjo, W. (2013) 'Symbolic Meaning of Money, Self-esteem, and Identification with Pancasila Values', Procedia - Social and Behavioral Sciences.

[18] Katuuk, O. M., Mewengkang, N. and Kalesaran, E. R. (2016) 'Peran Komunikasi Organisasi Dalam Meningkatkan Eksistensi Sanggar Seni Vox Angelica', Acta Diurna.

[19] Kurniawan, H. et al. (2011) 'E-CULTURAL HERITAGE AND NATURAL HISTORY FRAMEWORK: AN INTEGRATED APPROACH TO DIGITAL', in 2011 International Conference on Telecommunication Technology and Applications.

[20] Leonardo, E. and Andreani, F. (2015) 'PENGARUH PEMBERIAN KOMPENSASI TERHADAP KINERJA KARYAWAN PADA PT. KOPANITIA', Geophysical Research Letters.

[21] Li, H., Lee, K. C. and Lai, V. S. (2009) 'Interpersonal relationship needs of virtual behavior: From virtual communities to virtual worlds', in 15th Americas Conference on Information Systems 2009, AMCIS 2009.

[22] Mangkunegara, I. (2015) 'PENGARUH KARAKTERISTIK KEUANGAN DAN HASIL PEMERIKSAAN PADA KESEJAHTERAAN MASYARAKAT DI PROVINSI SUMATERA UTARA', Jurnal Tata Kelola \& Akuntabilitas Keuangan Negara.

[23] Mcleod, R. (2004) 'Management Information Systems Chapter 8', in Management Information Systems.

[24] Moenir, H. A. S. (2010) 'Manajemen pelayanan umum di Indonesia / H.A.S. Moenir', Manajemen pelayanan umum di Indonesia.

[25] Pratt, L. and Denison, D. (2000) 'The language of the Southey-Coleridge Circle', Language Sciences.

[26] Puspitasari, N. L. P. and Bendesa, I. K. G. (2016) 'Analisis Kualitas Pelayanan Publik di Badan Pelayanan Perijinan Terpadu Kabupaten Badung', E-Jurnal Ekonomi dan Bisnis Universitas Udayana 5.1 (2016).

[27] R.R., L. et al. (2017) 'The relationship between caregiver burden, patient behavioral symptoms, and memory clinic services', Journal of the American Geriatrics Society.

[28] Rasoolimanesh, S. M. et al. (2016) 'How Visitor and Environmental Characteristics Influence Perceived Crowding', Asia Pacific Journal of Tourism Research.
[29] Ratminto, R. (2005) 'Teknik, Mekanisme Dan Model Penilaian Kinerja Aparatur Pemerintah', Jurnal Administrasi Publik Unpar.

[30] Robbins, S. P. and Judge, T. A. (2008) 'Perilaku Organisasi Jilid II', Salemba Empat.

[31] Setiawan, daryanto (2017) 'Dampak Perkembangan Teknologi Informasi dan Komunikasi Terhadap Budaya Impact of Information Technology Development and Communication on', Jurnal Pendidikan.

[32] Sinambela, L. P. (2010) Reformasi Pelayanan PublikTeori Kebijakan dan Implementasi, Bumi Aksara.

[33] SISWANTO, S. (2019) 'ANALISIS LAPORAN KEUANGAN UNTUK MENILAI KINERJA KOPERASI PEGAWAI REPUBLIK INDONESIA (KPRI)', Jurnal Pendidikan Akuntansi Indonesia.

[34] Stein, J. W. (1975) 'Introducing public administration', Teaching Political Science.

[35] Tjiptono (2007) Strategi Pemasaran, edisi kedua, Edisi Kedua. Yogyakarta: Andi.

[36] Tjiptono, F. (2008) Kualitas pelayanan itu sendiri meliputi kualitas struktur, kualitas proses dan kualitas hasil, Yogyakarta : ANDI Offset.

[37] Tjiptono, F. and Chandra, G. (2005) 'Manajemen Kualitas Jasa', Yogyakarta. ANDI.

[38] Wilson, W. (2006) 'The Study of Administration', Political Science Quarterly.

[39] Yamin, M. and Golesorkhi, S. (2010) 'Cultural distance and the pattern of equity ownership structure in international joint ventures', International Business Review.

[40] Zahara, G. (2015) 'The influence of Competence Local Government Agencies and The Implementation Government of Internal Control System toward the Quality of Local Government Financial Statement', Research Journal of Finance and AccountingOnline). 